\title{
Are Vitamin Beverages Good for Dental Health?
}

\author{
A-Reum Kang ${ }^{1}$, Su-Hee Park', Jung-Woong Woo ${ }^{1}$, Da-Jung Hong ${ }^{1}$, Kyu-Ri Kim', \\ Chi-Yeong Sung ${ }^{1}$, Ji-Yeon Woo', Ju-Hui Jeong ${ }^{1,2}$, and Eun-Ha Jung ${ }^{1, \dagger}$ \\ ${ }^{1}$ Department of Dental Hygiene, Yonsei University Wonju College of Medicine, Wonju 26426, \\ ${ }^{2}$ Department of Dental Hygiene, Yonsei University Graduate School, Seoul 03722, Korea
}

\begin{abstract}
Background: Although the consumption of vitamin beverages has increased because of the recent interest in health and beauty, guidelines addressing appropriate consumption habits are lacking. Thus, the aim of this study was to investigate the erosive potential of several vitamin beverages and to propose guidelines for the appropriate intake of these drinks.

Methods: Five vitamin beverages were selected after a pre-investigation of the current beverage market. Coca-Cola and mineral water were selected as the control beverages. The $\mathrm{pH}$ of the beverages was measured with a calibrated $\mathrm{pH}$ meter, and the titratable acidity (TA) was determined by using $1 \mathrm{M}$ sodium hydroxide to reach pH 5.5 (TA5.5) and 7.0 (TA7.0). The screening method suggested by the International Organization for Standardization was used to measure $\mathrm{pH}$ variation $(\Delta \mathrm{pH})$ by using an under-saturated hydroxyapatite solution to determine the difference between the initial and final $\mathrm{pH}$ of the screening solution. All measurements were performed in triplicate.

Results: All vitamin beverages tested in this study exhibited a low pH (2.53 2.99), similar to Coca-Cola, which is known to be a highly acidic beverage. The highest TA5. 5 and TA7. 0 values of the vitamin beverages were $7.03 \mathrm{ml}$ and $8.81 \mathrm{ml}$, respectively. The largest change in $\mathrm{pH}$ determined by using the screening solution was found in Bacchus $\mathrm{D}(\Delta \mathrm{pH} 1.44 \pm 0.05)$. The mean $\Delta \mathrm{pH}$ of the vitamin beverages was 1.12 \pm 0.29 , which was higher than that of Coca-Cola (positive control, $\Delta \mathrm{pH} 0.58 \pm 0.05$ ) . Conclusion: Vitamin beverages exhibited an erosive potential capable of damaging enamel surfaces. Therefore, the frequency of vitamin beverage intake should be limited, and individuals consuming these drinks should try to restore normal oral $\mathrm{pH}$ as quickly as possible.
\end{abstract}

Key Words: Dental health, Erosive potential, Tooth erosion, Vitamin beverages

\section{Introduction}

Vitamin beverages are among several health-enhancing drinks, and the term usually refers to products containing antioxidants such as vitamins, minerals, and/or polyphenols ${ }^{1)}$. With the recently increasing interest in beauty and health, there has been a shift in the domestic beverage market, with the relative market share of vitamin beverages expanding ${ }^{2,3)}$. A domestic survey team found that one vitamin drink, Vita 500 (Kwang Dong Pharmaceutical Co., Seoul, Korea), had a high "drinking experience" (94.3\%). Furthermore, the intake frequency of vitamin beverages has been reported to be relatively high $(2 \sim 3$ times per week [19.9\%] for 2 3 weeks per month $[25.5 \%])^{4)}$. Although the vitamin beverage market and consumer demand continue to increase, there is a lack of consumer awareness and consideration about the effects of these beverages on health ${ }^{5)}$. A survey reported that a high proportion (approximately $32.9 \%$ ) of the food ingredient labels of vitamin beverages are not being read by consumers $^{4)}$. Many studies have shown that there are numerous side effects of excessive vitamin intake. However, very few studies have examined consumer perceptions of the various ingredients in vitamin beverages. A study of 
energy drinks similar to vitamin beverages found that $42.3 \%$ of energy drink consumers did not worry about the ingredients ${ }^{6)}$.

One health problem to consider when consuming vitamin beverages is dental erosion. Tooth erosion refers to damage to the hard tissue of teeth that is caused by exposure to acids, such as those from the diet and gastric fluid. Several studies have reported that dental caries or erosion can occur when teeth are continually exposed to highly acidic environments $(\mathrm{pH}<5.5)^{7}$. Vitamin beverages contain a variety of vitamins including ascorbic acid (vitamin C), which is confirmed to have high acidity with low $\mathrm{pH}$ (approximately $\mathrm{pH} 2.5 \sim 3.0$ ). The intake of vitamin beverages may therefore reduce tooth surface hardness and cause tooth erosion ${ }^{5}$. Thus, before consuming vitamin beverages, it is necessary to understand these ingredients and consider their effects on teeth.

Although this need has often been mentioned, there have been few studies addressing the effects of vitamin beverages on dental hard tissues and methods to overcome these problems. Therefore, this study aims to evaluate the potential for dental erosion from some vitamin beverages in Korea and to propose clinical guidelines for appropriate vitamin beverage intake.

\section{Materials and Methods}

\section{Selection of experimental beverages}

Among the 30 types of vitamin beverages marketed in 11 pharmacies, marts, and convenience stores around $\mathrm{Y}$ University in Wonju, Korea, three best-selling (Vita 500; Kwang Dong Pharmaceutical Co., Seoul, Korea; Bacchus-D; Dong-A Pharmaceutical, Seoul, Korea; Oronamin C; Dong-A Otsuka, Seoul, Korea) and two high-market vitamin beverages (Daily Lemon $1000 \mathrm{C}+$; Lotte Chilsung Beverage Co., Seoul, Korea; Glaceau Vitamin WaterDragon Fruits; Coca-Cola Korea, Seoul, Korea) were selected as the experimental group. Mineral water (Jeju Samdasu; Jeju Special Self-Governing Province Tourism Co., Jeju, Korea) was selected as the negative control, and Coca-Cola (Coca-Cola Korea), which is known to be highly acidic, was used as the positive control (Table 1). The selected beverages were evaluated by using various methods.

Table 1. Control and Experiment Groups Used in This Study

\begin{tabular}{|c|c|c|c|}
\hline \multirow{2}{*}{ Brand name } & \multirow{2}{*}{ Manufacturer } & \multicolumn{2}{|r|}{ Chemical composition } \\
\hline & & Acid & Other \\
\hline Jeju Samdasu & $\begin{array}{l}\text { Jeju Special } \\
\text { Self-Governing } \\
\text { Province Tourism Co. }\end{array}$ & - & - \\
\hline Glaceau Vitamin Water & Coca-Cola Korea & Citric acid & $\begin{array}{l}\text { Fructose, white sugar, vitamin C, vitamin A, vitamin B, } \\
\text { guarana extract, gum arabic, coloring matter, natural } \\
\text { favoring substance }\end{array}$ \\
\hline Daily Lemon $1000 \mathrm{C}+$ & $\begin{array}{r}\text { Lotte Chilsung } \\
\text { Beverage Co. }\end{array}$ & Citric acid & $\begin{array}{l}\text { White sugar, sodium citrate, vitamin } \mathrm{C} \text {, lemon juice, acacia } \\
\text { honey, coloring matter, natural favoring substance }\end{array}$ \\
\hline Bacchus D & Dong-A Pharmaceutical & $\begin{array}{l}\text { DL-carnitine } \\
\text { hydrochloride }\end{array}$ & $\begin{array}{l}\text { Taurine, inositol, nicotinic acid amide, vitamin } B_{1} \text {, vitamin } \\
\mathrm{B}_{2} \text {, vitamin } \mathrm{B}_{3} \text {, vitamin } \mathrm{B}_{6} \text {, caffeine }\end{array}$ \\
\hline Vita 500 & $\begin{array}{l}\text { Kwang Dong } \\
\text { Pharmaceutical Co. }\end{array}$ & Citric acid & $\begin{array}{l}\text { Liquid fructose, concentrated apple juice, vitamin } \mathrm{C} \text {, } \\
\text { vitamin } \mathrm{B}_{2} \text {, hyaluronic acid, synthetic flavoring, } \\
\text { Trisodium citrate, pectin, taurine, DL-apple acid, orange } \\
\text { extract }\end{array}$ \\
\hline Oronamin C & Dong-A Otsuka & Citric acid & $\begin{array}{l}\text { White sugar, liquid fructose, carbonate dioxide, acacia } \\
\text { honey, vitamin } \mathrm{C} \text {, caffeine, vitamin } \mathrm{B}_{2} \text {, synthetic } \\
\text { flavoring, coloring matter }\end{array}$ \\
\hline Coca-Cola & Coca-Cola Korea & Phosphoric acid & $\begin{array}{l}\text { Carbonate dioxide, high fructose corn syrup, white sugar, } \\
\text { caramel, coloring matter, natural favoring substance, } \\
\text { caffeine }\end{array}$ \\
\hline
\end{tabular}




\section{Measurement of beverage $\mathrm{pH}$}

The $\mathrm{pH}$ of each experimental beverage $(100 \mathrm{ml})$ was measured while the beverage was being stirred by using a pH meter (Orion 4 star; Thermo Fisher Scientific, Beverly, MA, USA), which was calibrated with a standard buffer solution. Measurements were repeated three times, and the results are expressed as the average of the three values.

\section{Titratable acidity of the beverages}

The titratable acidity (TA) was measured by adding $1 \mathrm{M}$ sodium hydroxide $(\mathrm{NaOH})$ to evaluate the buffering capacity of the experimental beverages. TA5.5 was defined as the volume of $1 \mathrm{M} \mathrm{NaOH}$ added to reach a critical $\mathrm{pH}$ of 5.5, at which demineralization could occur on the tooth surface as a result of the acidity of the experimental beverage. TA7.0 was defined as the volume of $1 \mathrm{M} \mathrm{NaOH}$ added to reach a neutral $\mathrm{pH}$ (7.0). The $\mathrm{pH}$ of $100 \mathrm{ml}$ of the experimental beverages was measured while the beverage was being stirred, and $1 \mathrm{M} \mathrm{NaOH}$ was added in $0.5 \mathrm{ml}$ aliquots to confirm the change in $\mathrm{pH}$. The total volume of $1 \mathrm{M} \mathrm{NaOH}$ added was recorded, after repeated additions to reach $\mathrm{pH} 5.5$ or 7.0. The TA of the experimental beverages was measured three times, and the results are expressed as the average of the three values.

\section{Evaluation of erosive potential according to the International Organization for Standardization method}

To evaluate the possibility of tooth erosion from vitamin beverages, the method proposed by the International
Organization for Standardization (ISO) was used ${ }^{8,9)}$. A calcium phosphate solution $(\mathrm{pH} 5.05 \pm 0.05)$, prepared immediately before use, was used to represent slightly unsaturated hydroxyapatite. This solution was used only on the day of preparation. The $\mathrm{pH}$ of the calcium phosphate solution $(25 \mathrm{ml})$ was measured while it was being stirred; the experimental beverages $(0.25 \mathrm{ml})$ were then added, and the $\mathrm{pH}$ was measured again. The difference in $\mathrm{pH}$ before and after the addition of the experimental beverage was defined as the change in $\mathrm{pH}(\Delta \mathrm{pH})$. The $\Delta \mathrm{pH}$ value was calculated from three repeated measurements.

\section{Statistical analysis}

The relative potential for dental erosion between each beverage sample was evaluated with one-way analysis of variance (ANOVA), followed by Tukey's test to identify statistically significant differences between the samples. Statistical analysis was performed by using IBM SPSS ver. 25.0 software (IBM Corp., Armonk, NY, USA) with a significance level of $5 \%$ for the determination of statistical significance.

\section{Results}

\section{Measurement of beverage $\mathrm{pH}$}

The results of this experiment were calculated as the average value after a total of three evaluations for all beverages. The Coca-Cola selected as the positive control in this experiment had a $\mathrm{pH}$ of 2.39 , and the $\mathrm{pH}$ of the mineral water (the negative control) was 7.69. The

Table 2. Potential for Dental Erosion from Vitamin Beverages

\begin{tabular}{|c|c|c|c|c|}
\hline Brand name & $\mathrm{pH}(\mathrm{pH})$ & TA $5.5(\mathrm{ml})$ & TA $7.0(\mathrm{ml})$ & ISO $(\Delta p H)$ \\
\hline Jeju Samdasu & $7.69 \pm 0.08^{\mathrm{a}}$ & - & - & $-0.02 \pm 0.04^{\mathrm{a}}$ \\
\hline Glaceau Vitamin Water & $2.99 \pm 0.04^{\mathrm{b}}$ & $0.97 \pm 0.13^{\mathrm{a}}$ & $1.19 \pm 0.15^{\mathrm{a}}$ & $0.77 \pm 0.09^{b}$ \\
\hline Daily Lemon $1000 \mathrm{C}+$ & $2.86 \pm 0.08^{\mathrm{b}, \mathrm{c}}$ & $7.03 \pm 0.10^{\mathrm{b}, \mathrm{c}}$ & $7.96 \pm 0.17^{\mathrm{b}, \mathrm{c}}$ & $1.30 \pm 0.06^{\mathrm{c}}$ \\
\hline Bacchus D & $2.53 \pm 0.05^{\mathrm{d}}$ & $6.74 \pm 0.13^{\mathrm{b}}$ & $8.81 \pm 0.13^{b}$ & $1.44 \pm 0.05^{\mathrm{c}}$ \\
\hline Vita 500 & $2.80 \pm 0.04^{\mathrm{c}}$ & $6.47 \pm 0.31^{\mathrm{c}}$ & $7.53 \pm 0.34^{\mathrm{c}}$ & $1.29 \pm 0.11^{\mathrm{c}}$ \\
\hline Oronamin C & $2.71 \pm 0.07^{\mathrm{c}}$ & $2.37 \pm 0.24^{\mathrm{d}}$ & $3.34 \pm 0.90^{\mathrm{d}}$ & $0.81 \pm 0.18^{b}$ \\
\hline Coca-Cola & $2.39 \pm 0.03^{\mathrm{d}}$ & $0.81 \pm 0.02^{\mathrm{a}}$ & $2.05 \pm 0.19^{\mathrm{a}}$ & $0.58 \pm 0.05^{\mathrm{b}}$ \\
\hline
\end{tabular}

Values are presented as mean \pm standard deviation.

TA: titratable acidity.

${ }^{a-d}$ Different letters within the same column indicate significant differences between groups according to Tukey post hoc analysis at alpha $=0.05$. 
beverage with the highest $\mathrm{pH}$ was the Glaceau Vitamin Water (pH 2.99) and the one with the lowest was Bacchus $\mathrm{D}$ ( $\mathrm{pH}$ 2.53) (Table 2). All of the experimental samples, except for the mineral water, exhibited acidic properties within a $\mathrm{pH}$ range of 2.00 to 3.00 .

\section{TA of the beverages}

The TA values of the beverages, according to the volume of $1 \mathrm{M} \mathrm{NaOH}$ added to evaluate buffer capacity, are summarized in Table 2. The volumes of $1 \mathrm{M} \mathrm{NaOH}$ solution (TA5.5, TA7.0) added to restore the low $\mathrm{pH}$ of the vitamin beverages to 5.5 and 7.0 were 0.97 to $7.03 \mathrm{ml}$ and 1.19 to $8.81 \mathrm{ml}$, respectively. The TA5.5 measurements indicated that a large volume of $\mathrm{NaOH}$ was required to reach pH 5.5, in the order of Daily Lemon $1000 \mathrm{C}+$, Bacchus D, Vita 500, Oronamin C, Glaceau Vitamin Water, and Coca-Cola. Large volumes of $\mathrm{NaOH}$ were also required to achieve $\mathrm{pH} 7.0$, in the order of Bacchus-D, Daily Lemon 1000 C+, Vita 500, Oronamin C, Coca-Cola, and Glaceau Vitamin Water. Significant differences were found between the samples in both TA5.5 and TA7.0 $(\mathrm{p}<$ 0.05). For Bacchus-D, Daily Lemon $1000 \mathrm{C}+^{+}$, and Vita 500 , more than $6.5 \mathrm{ml}$ of additional $\mathrm{NaOH}$ were required for $\mathrm{pH}$ recovery to 5.5 and 7.0, compared with the other samples. The TA value for the mineral water, with $\mathrm{pH}>$ 7.0 could not be measured.

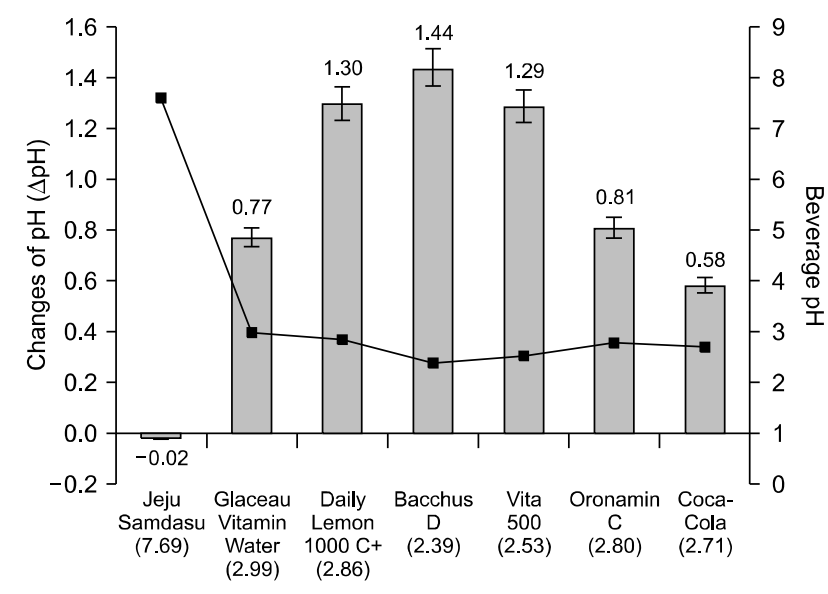

Fig. 1. The test results for erosive potential of vitamin beverages with $\mathrm{Ca}-\mathrm{PO}_{4}$ solution. The bar graph means that changes of $\mathrm{Ca}-\mathrm{PO}_{4}$ solution after addition of experiment beverages. A line is $\mathrm{pH}$ of experiment beverages.

\section{Evaluation of erosive potential according to the International Organization for Standardization method}

The difference between the initial $\mathrm{pH}$ and final $\mathrm{pH}$ of the calcium phosphate solution was measured and converted into a $\Delta \mathrm{pH}$ value. As a result, the $\Delta \mathrm{pH}$ values of the vitamin beverages were -0.02 to 1.44 (Table 2, Fig. 1). Bacchus D, Daily Lemon $1000 \mathrm{C}+$, and Vita 500 caused a greater change in the $\mathrm{pH}$ of the calcium phosphate solution than the other samples $(p<0.05)$ (Table 2$)$. In the cases of Glaceau Vitamin Water and Oronamin C, the $\mathrm{pH}$ change was slightly higher than that of the positive control group (Coca-Cola); however, there was no significant difference between the samples $(\mathrm{p}=0.486)$.

\section{Discussion}

Recently, the Food Information Statistics System reported that concerns about health and sugar intake have resulted in reduced production of fruit-based drinks, and alternative consumption patterns have emerged, including an increase in the consumption of low-calorie carbonated drinks, ionic and/or vitamin beverages ${ }^{3,10}$. Nevertheless, there is a lack of research investigating the effects of vitamin beverages on teeth to reflect this recent increase in consumption. Therefore, it is necessary to investigate the effects of vitamin beverages on oral health and to produce - or at least, propose-guidelines for healthy beverage consumption.

Approximately $48.2 \%$ of beverage sales in the Korean market occur in convenience stores, with approximately 30 types of vitamin beverages circulating in the country ${ }^{10}$. After preliminary research, five types of beverage, which had the highest sales rates and market shares, were selected as the experimental group (Table 1) for an evaluation of the possibility of tooth erosion from vitamin beverages by using various methods.

Changes in oral $\mathrm{pH}$ can be caused by a variety of factors, including saliva and bacteria ${ }^{11}$. This can directly affect hard tissue changes, such as dental caries and dental erosion. In particular, the $\mathrm{pH}$ level is considered to be the chemical factor in beverages that significantly affects the degree of enamel erosion ${ }^{12,13)}$. Therefore, this study 
attempted to evaluate the potential for dental erosion from vitamin beverages by measuring the $\mathrm{pH}$ of the beverages. This $\mathrm{pH}$ measurement experiment revealed that the average $\mathrm{pH}$ of the five vitamin beverages was 2.78 , which was not significantly different from that of Coca-Cola $(\mathrm{pH}$ 2.39) (Table 2). A previous study reported that Coca-Cola deposited for 2 minutes reduced surface hardness by approximately $6 \%$ and tooth hardness was reduced by approximately $10 \%$ after repeated exposure. In particular, approximately 7.5 to $16 \%$ of the surface hardness was reduced in dentin ${ }^{14)}$. Energy drinks, which are similar to vitamin beverages, also had high tooth erosive potential with low $\mathrm{pH}$ and buffering capacity ${ }^{15,16}$. This is presumed to be a result of several ingredients in these beverages and the vitamin beverages, including phosphoric acid and citric acid. Vitamin beverages also contain added sugars to reduce the sourness and bitterness of the vitamins (Table 1). According to the Stephen curve, a representative theory of tooth demineralization, the $\mathrm{pH}$ is lower in sugarcontaining foods or beverages. Moreover, continual exposure to an environment below $\mathrm{pH} 5.0$ to 5.5 for 20 to 30 minutes can cause tooth demineralization ${ }^{17}$. Therefore, given the average $\mathrm{pH}$ of the beverages investigated in this study (2.78), it is necessary to remove remnant components after these beverages are consumed to restore and maintain neutral $\mathrm{pH}$ in the oral cavity.

In general, it is believed that tooth erosion is significantly influenced by the acidity of beverages; however, previous studies have reported that acidity and tooth erosion are not directly proportional. This is because the acidity of the beverage is changed to TA in the oral cavity ${ }^{18)}$. Highly buffered acidic beverages are more difficult to change to proper acidity that does not cause dental erosion in the oral cavity and cause more demineralization $^{19)}$. In other words, TA means that the acidic beverage is resistant to a change in $\mathrm{pH}$ value. Accordingly, this study attempted to confirm the potential for tooth erosion from vitamin beverages by evaluating buffering capacity as well as $\mathrm{pH}$ value. As a result, TA7.0 was evaluated, and the titratable acidity of four of the vitamin drinks was higher than that of Coca-Cola. That is, more $\mathrm{NaOH}$ solution was needed in four of the vitamin beverages (Bacchus D, Oronamin C, Daily Lemon 1000
$\mathrm{C}+$, Vita 500) to reach the neutral $\mathrm{pH}$ of 7.0 (TA7.0 3.34 $\sim 8.81 \mathrm{ml}$ ) than was required for Coca-Cola. In the case of Daily Lemon $1000 \mathrm{C+}$, Bacchus D, and Vita 500, 7.5 to $8.8 \mathrm{ml}$ of $\mathrm{NaOH}$ solution were required to reach a $\mathrm{pH}$ of 7.0, which demonstrates that an individual's buffering capacity needs to be substantial for acidic environments after beverage intake. In the TA5.5 experiment, all beverages required more $\mathrm{NaOH}$ than Coca- Cola. As mentioned, it is necessary to be careful when consuming these types of beverages because they may damage the hard tissues at $\mathrm{pH}<5.5$. The reason why strong buffering capacity is required in vitamin beverage intake is presumably because of the properties of the acid contained in the beverage. Food acids can be classified into organic and inorganic. Coca-Cola contains phosphoric acid, which is an inorganic acid, and citric acid, which is an organic acid, both of which are also included in most vitamin beverages. In the case of organic acids, the initial concentration of hydrogen ions is relatively low, but the degree of dissociation is low. Therefore, the acid dissociates slowly in the oral cavity, and the oral $\mathrm{pH}$ recovery rate is slow $^{20,21)}$. To overcome this, efforts to restore and maintain a neutral oral environment in the individual or to lower the buffering capacity of the vitamin beverage should be attempted. In other words, by considering the chelating of organic acids, a buffering effect can be achieved by supplementing the surrounding environment with calcium and phosphorus ${ }^{22)}$. When these factors are considered, vitamin beverages should contain calcium or phosphorus to improve oral buffering, or the retention of vitamin beverages should be minimized by active management of oral hygiene.

Finally, an evaluation was performed with calcium phosphate solution as suggested by the ISO to evaluate the erosive potential of vitamin beverages ${ }^{8)}$. In this method, the dental hard tissue is represented by calcium phosphate solution. The difference between the initial $\mathrm{pH}$ of the calcium phosphate solution before injection and the lowest $\mathrm{pH}$ value after injection was converted into a $\Delta \mathrm{pH}$ value. The results show that the $\mathrm{pH}$ change of all experimental beverages (Glaceau Vitamin Water, Daily Lemon 1000 $\mathrm{C}+$, Vita 500, Oronamin C, Bacchus D) was higher than that of the control (Table 2, Fig. 1). In particular, Bacchus 
D and Vita 500, which have the highest sales share of the beverage market, exhibited higher erosion potential than the other drinks, with $\Delta \mathrm{pH}$ values of 1.29 to 1.44 . According to the ISO suggestions, the use of these products should be limited because the risk for tooth erosion is increased when the change in $\mathrm{pH}$ is $>1.0^{8)}$. Therefore, efforts to minimize oral damage caused by low $\mathrm{pH}$ are necessary.

Although not reflected by the data presented in Table 2, the ISO values demonstrated high correlation, with 0.91 and 0.92 at TA5.5 and TA7.0, respectively. This is also presumed to be caused by calcium phosphate. As mentioned earlier, the calcium phosphate concentration can affect the $\mathrm{pH}$ value ${ }^{23,24)}$. Significant changes in the calcium phosphate solution mean that vitamin beverages have a strong inherent property to maintain acidity ${ }^{25)}$. The TA and ISO test results may be similar because of these effects. In addition, it was confirmed that the $\mathrm{pH}$ changes depend on the initial $\mathrm{pH}$ (Fig. 1). On the basis of these results, beverage manufacturers and consumer organizations should make efforts to regularly screen drinks and report the results for healthier beverage intake across the nation. Furthermore, the ISO method will help screen for the possibility of tooth erosion from drinks including vitamin beverages.

In this in vitro study, certain vitamin beverages were evaluated by using various methods to assess their effects on dental health. However, there are limitations as a result of the various factors (saliva flow, beverage intake frequency, etc.) that may occur in the oral cavity. Nevertheless, it is an advantage of this study that useful information could be provided to the public by using comparatively simple and accurate methods.

The results of this study revealed that vitamin beverages may have an adverse effect on dental health, although this may vary among individuals. However, if the time spent in the oral cavity when a drink is ingested is considered, if the natural balance is not recovered after such a rapid change in $\mathrm{pH}$, the effect will definitely be significant. Therefore, based on these findings, it is necessary to raise awareness in the public and manufacturers about the fact that vitamin beverages have a significant effect on dental erosion. Furthermore, when individuals who regularly enjoy vitamin beverages visit the dental clinic, proper oral hygiene management should be recommended immediately after consumption to increase the $\mathrm{pH}$ of the oral cavity as quickly as possible.

\section{Notes}

\section{Conflict of interest}

No potential conflict of interest relevant to this article was reported.

\section{Ethical approval}

This in vitro study does not require an IRB review.

\section{Author contributions}

Conceptualization: Eun-Ha Jung. Experiment and Data collection: Su-Hee Park, Jung-Woong Woo, Da-Jung Hong, Kyu-Ri Kim, Chi-Yeong Sung, Ji-Yeon Woo. Formal analysis: Su-Hee Park, Jung-Woong Woo, Da-Jung Hong, Kyu-Ri Kim, Chi-Yeong Sung, Ji-Yeon Woo, Ju-Hui Jeong. Writing - original draft: A-Reum Kang, Eun-Ha Jung.

\section{ORCID}

A-Reum Kang, https://orcid.org/0000-0003-1647-9290

Su-Hee Park, https://orcid.org/0000-0002-7366-8226

Jung-Woong Woo, https://orcid.org/0000-0001-6971-0359

Da-Jung Hong, https://orcid.org/0000-0002-6244-7882

Kyu-Ri Kim, https://orcid.org/0000-0001-9127-7248

Chi-Yeong Sung, https://orcid.org/0000-0002-4398-552X

Ji-Yeon Woo, https://orcid.org/0000-0002-4469-1136

Ju-Hui Jeong, https://orcid.org/0000-0002-0629-2652

Eun-Ha Jung, https://orcid.org/0000-0002-3737-5899

\section{Acknowledgements}

I would like to thank TA Ji-Won Shin for her assistance in the administrative process. This paper was conducted with the support of student research funds from Yonsei University Wonju College of Medicine in 2019.

\section{References}

1. Heckman MA, Sherry K, Gonzalez De Mejia E: Energy drinks: an assessment of their market size, consumer demo- 
graphics, ingredient profile, functionality, and regulations in the United States. Compr Rev Food Sci Food Saf 9: 303-317, 2010. https://doi.org/10.1111/j.1541-4337.2010.00111.x

2. Food Information Statistics System: 2017 processed food segment market report-beverage market. Food Information Statistics System, Naju, pp.25-45, 2017.

3. Food Information Statistics System: Summary report on the 2019 processed food segment market - beverage market. Food Information Statistics System, Naju, pp.1-2, 2019.

4. Department E: U\&A survey for energy drinks. Macromillembrain, Seoul, pp.211-249, 2012.

5. Kim HN, Yoon TL, Min JH: Evaluation of the potential of commercial vitamin drinks to induce tooth erosion. J Dent Hyg Sci 19: 154-161, 2019. https://doi.org/10.17135/jdhs.2019.19.3.154

6. Park JS, Lee EJ, Lee CY, Jung HS: Consumption status, risk awareness and experience of adverse effects of high-caffeine energy drink among university students. J Korean Public Health Nurs 29: 102-114, 2015. https://doi.org/10.5932/JKPHN.2015.29.1.102

7. Imfeld T: Dental erosion. Definition, classification and links. Eur J Oral Sci 104: 151-155, 1996. https://doi.org/10.1111/j.1600-0722.1996.tb00063.x

8. International Organization for Standardization: Dentistryscreening method for erosion potential of oral rinses on dental hard tissues, ISO28888. ISO, Geneva, Switzerland, pp.7-11, 2013.

9. Kim SK, Park SW, Kang SM, Kwon HK, Kim BI: Assessment of the erosive potential of carbonated waters. $\mathbf{J}$ Korean Acad Oral Health 39: 273-279, 2015. https://doi.org/10.11149/jkaoh.2015.39.4.273

10. Food Information Statistics System: 2019 processed food segment market report-beverage market. Food Information Statistics System, Naju, pp.32-58, 2019.

11. Loke C, Lee J, Sander S, Mei L, Farella M: Factors affecting intra-oral pH - a review. J Oral Rehabil 43: 778-785, 2016. https://doi.org/10.1111/joor.12429

12. Dong YM, Pearce EI, Yue L, Larsen MJ, Gao XJ, Wang JD: Plaque $\mathrm{pH}$ and associated parameters in relation to caries. Caries Res 33: 428-436, 1999. https://doi.org/10.1159/000016547

13. Honório HM, Rios D, Júnior ES, de Oliveira DS, Fior FA, Buzalaf MA: Effect of acidic challenge preceded by food consumption on enamel erosion. Eur J Dent 4: 412-417, 2010. https://doi.org/10.1055/s-0039-1697861

14. Jeon HS, Kang SM, Kwon HK, Kim BI: Influence of toothbrushing on eroded enamel and dentin by carbonated soft drink. J Korean Acad Dent Health 32: 170-181, 2008.

15. Jeong MJ, Jeong SJ, Son JH, et al.: A study on the enamel erosion caused by energy drinks. J Dent Hyg Sci 14: 597-609, 2014. https://doi.org/10.17135/jdhs.2014.14.4.597

16. Oh HN, Lee HJ: The effect of energy drink on enamel erosion. J Dent Hyg Sci 15: 419-423, 2015. https://doi.org/10.17135/jdhs.2015.15.4.419

17. Miller WD: The agency of acids in the production of caries of the human teeth, with comparative analysis of carious dentine and dentine softened by acids. Dent Cosm 25: 337-344, 1883.

18. Meurman JH, ten Cate JM: Pathogenesis and modifying factors of dental erosion. Eur J Oral Sci 104: 199-206, 1996. https://doi.org/10.1111/j.1600-0722.1996.tb00068.x

19. Larsen M, Nyvad B: Enamel erosion by some soft drinks and orange juices relative to their $\mathrm{pH}$, buffering effect and contents of calcium phosphate. Caries Res 33: 81-87, 1999. https://doi.org/10.1159/000016499

20. Yoshimura N, Okazaki M, Nakagawa N: Simultaneous estimation of the dissociation constant and concentration by a linear least-squares method with non-negative constraint. Anal Sci 16: 1331-1335, 2000. https://doi.org/10.2116/analsci.16.1331

21. Seo DG, Kim HS, Jeong SH, Choi CH, Kwon HS, Kim BI: Measurement of intra-plaque $\mathrm{pH}$ and recovery speed of soft drinks by telemetry. J Korean Acad Dent Health 30: 151-162, 2006.

22. Kim EJ, Jin BH: Effects of titratable acidity and organic acids on enamel erosion in vitro. J Dent Hyg Sci 19: 1-8, 2019. https://doi.org/10.17135/jdhs.2019.19.1.1

23. Park SW, Kim SK, Jung EH, Kwon HK, Kim BI: Erosive potential of several fruit-flavored liquors in Korea. J Korean Dent Assoc 54: 521-528, 2016.

24. Kim BR, Min JH, Kwon HK, Kim BI: Analysis of the erosive effects of children's beverages using a pH-cycling model. J Korean Acad Oral Health 37: 141-146, 2013. https://doi.org/10.11149/jkaoh.2013.37.3.141

25. Dawes C: What is the critical $\mathrm{pH}$ and why does a tooth dissolve in acid? J Can Dent Assoc 69: 722-724, 2003. 